\title{
Preliminary Report of the Princeton University Expedition to Abyssinia.
}

By Enno Littmann.

With contributions by Richard Sundström.

Under the patronage of Mr. Robert GarRert of Baltimore, a trustee of Princeton University, by whose generosity and personal interest Oriental scholarship in America has been supported and furthered for a number of years, I undertook to make an expedition to Abyssinia in the fall and winter of $1905-1096$. My object was

I) to study the Tigrē and Tigriña languages;

2) to visit the ruins of the ancient kingdom of Aksum in order to secure reliable reproductions of the known inscriptions, to search for new inscriptions and to study them in connection with the ruins themselves;

3) to collect manuscripts.

While I was on my way to Abyssinia, an expedition with a somewhat similar purpose was being organized at Berlin under the auspices of His Majesty the German Emperor. Shortly after I arrived in the Colonia Eritrea, I was asked to lead this expedition to Aksum. Considering the fact that, at all events, my original plans were to be modified by this new combination of circumstances, Mr. GaRRETT kindly agreed that I might, under his patronage and as a member of Princeton University, carry out only the first of the three above named purposes and as much of the third as possible, whereas the second might be left entirely to 
the German Expedition. ") A preliminary report of the latter is to be found in the Abhandlungen der Berliner Akademie der Wissenschaflen, 1906, under the title "Vorbericht der Deutschen Aksum-Expedition von E. Littarano und D. KrencKer".

During the month of September 1905 I prepared myself in Rome for my work. In this I was much encouraged and helped by my friends Professor Goidr, of the University of Rome, and Dr. Conts RossinI who had himself explored large parts of the Colonia Eritrea, discovered several new and important inscriptions and, with his indefatigable zeal, was able to do highly valuable linguistic work notwithstanding all the duties and annoyances of his office as Capo degli Affari Civili at Asmara. ${ }^{2}$ ) I left Naples in the beginning of October and arrived at Massaua, the main sea-port of the Colonia Eritrea, shortly after the middle of that month. From here I went to Asmara by way of Ghinda (Gondac). At Asmara I stayed a week, partly on account of a slight attack of fever, partly in order to organize a small caravan for my visit to the north. To His Excellency F. Martini, R. Commissario Civile della Colonia Eritrea, my sincere thanks are due for the interest which he took in my work. And from the very beginning $I$ received the most active support from the Swedish missionaries whose kindness, knowiedge of the country, and self-denial cannot be too highly esteemed.

My little caravan consisted of six mules. Thanks to the energy and activity of the Italian Government it is now practically safe to travel anywhere within the boundaries of the Colonia Eritrea. I took the direct road to Gheleb (Gäläb), the capital of the Mensa (Mänsa') tribe and a station of the Swedish mission, where I intended

I) With the exception of Adulis; cf. Herr SunDSTRöm's report below.

2) Cf. his Ricerche e studi sull' Etiopia, in Bollettino della Società Geografica Italiana, 1900. 
to study the Tigrē language. From Asmara to Cheren (Käräun) runs a very well built highroad. ${ }^{x}$ ) I followed this road and left it at a place south of Däqqi Maharī, a village with some signs of an earlier habitation, near which the Greek inscription published below was found. At Wārā, the point where the Tigriña and the Tigrē languages meet, I halted for the night. On the next day the high and steep mount Irā was passed, and after a very difficult descent into the valley of Qəruh and a tiring march along a dry river bed, Gäläb was reached at nightfall. Here I was kindly received by Herr RoDén, the chief of the missionary station, and his companion Herr Sundsteons, whose knowledge of Tigrē had formerly been of great service to me.

At Gäläb I stayed nearly two months. I made, however, a few short excursions into the nearest surroundings and one excursion of $3{ }^{y} / 2$ days to Kärän and Däbra Sinā. All the rest of the time was devoted to the study of the Tigre language, in the main as spoken by the Mänsa' tribe, whose manners and customs, traditions and beliefs were written down from the mouths of the natives and to some extent illustrated by photographs. I left Gäläb on December 22 and returned to Asmara by practically the same road: one night was spent near Qəruh, another at Gürītāt; the ascent of mount İrā was now easier than the descent, because in the meanwhile Herr Roden had, with his pupils, cut a mule-road up to the top of that cragged and hitherto trackless mountain. From Asmara I visited Zazega (Șa $a d z \partial g \bar{a}$ ), the station of Herr Svensson, the venerable Nestor of the Swedes in Abyssinia, and Belesa (Bäläza) where Dr. WinQvist, one of the foremost Tigriña scholars, is stationed. Again I went down to the sea-shore and spent $2^{\mathrm{x}} / 2$ days at Massaua. Here begins the work of

1) Similar roads exist from Asmara to Ghinda, to Saganeiti and to Adi Ugri; the latter two are to be continued to the Abyssinian frontier. 
the German Expedition, which is described in the above named report.

Before I give an account of my work, a few words may be said about the Swedish mission in Abyssinia. The first of these heroic men and women who often enough have risked their health and their lives in order to give the poor and wretched Abyssinians some conception of a higher civilization and higher religious ideals, arrived at Massaua when that town was still under Egyptian rule. Soon they went up to the highlands, but there one of them was murdered, others died or were driven back: even in those days the mission-work was carried on among the pagan Kunama, in the western part of the Colonia Eritrea, and a station existed at Gäläb. But everything had to be abandoned outside of Massaua and the district near Monkullo until the Italians took possession of the highlands north of the river Mareb (Māääb) under General Baldissera (1888-i89o). Since then the work has been growing and spreading constantly. At present there are 3 stations among the people speaking Tigriña (in Hamasen, Hamāsēn): Asmara, Zazega, Belesa; 2 among the tribes who speak Tigrē: Monkullo, Gäläb; I among the pagan Kunama: Kulluku. Asmara is at present the largest and most important station. Here the mission press is established in which many books are printed in several different East-African languages: Ethiopic, Amharic, Tigriña, Tigrē, Kunama, Galla, and even Suaheli. Herr Ivarson, the director of this station, has been of great help to me on several occasions. From the mere scholarly standpoint the work of the missionaries in studying these languages and creating written literatures where formerly there were none, is of the greatest value and importance. On the other hand, their personal influence upon the natives must needs be a most beneficial one. 


\section{The Tigrē Language.}

Among the languages spoken in the Colonia Eritrea the Tigre language is the most important for several reasons. First, the people using it as their mother tongue are more numerous than any other linguistic community within the Italian possessions; secondly, it is spreading very rapidly to tribes of different nationality and takes, in a way, the place of a lingua franca, competing in this re'spect with the Arabic in those regions; thirdly, it is of great philological interest, since it is the most archaic of the present Semito-A byssinian languages and, although not

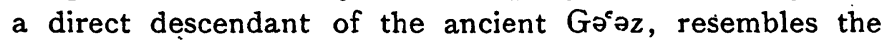
latter more than the Tigriña, which is directly derived from Gəoz, and since it is almost a connecting link between the Asiatic and the African Semitic.

The region where Tigre is spoken extends from the Red Sea in the East to Kassala in the West, and from Massaua and Arkiko (Dökhonō) in the South to near Suakin (Sawākin) in the North. It borders and partly trespasses on the territories of the following languages: Arabic in the East and North; Saho (or Assaorta) in the SouthEast; Tigriña in the middle South; Kunama (or Bāzēn) in the South-West; Bāryā in the East; Hədārab (the language of the Hadendoa) in the East and North; the Bilenn, or language of the Bogos, is almost entirely surrounded by the Tigre and, like others, in danger of being entirely absorbed by it.

Massaua (Bäșé in Tigrê, Moșinzac in Tigriña) is bilingual: Arabic and Tigrē. Naturally the Arabic words in Tigre are here quite numerous; and even Italian words are used by the natives. At the same time $I$ heard Saho, Tigriña and Bāryā spoken by people from the continent. For a day's journey south of Massaua both Tigrē and Saho are understood, just as in Addi Caiè ('Addż Gayell), for instance, Saho and Tigriña are spoken. A line from Mas- 
saua to Ghinda and from there to Keren passing through Waraa would be the southern border of Tigrẽ in this part of the Colony. There is only a small enclave of Tigriña at Däbra Sinā. Of the tribes that use Tigré exclusively, the Mänsa', the Habāb and the Măryã are the most important and numerous. The Mänsa' are semi-nomads: they till the soil and have certain villages where they have their homes and where they spend only a few months: the larger part of the year, however, they stay on their fields, i. e. in the winter in the low-lands, in the summer in the highlands, according to the natural conditions of the country. The rainy season of the low-lands corresponds to our winter, that of the highlands to our summer: consequently the Mänsa' plough, sow, and harvest twice a year. The tribe is divided into two sub-tribes: Bēt $A$ brəhē and Bēt Šăhaqán; both are partly Christian, partly Muhammedan. The Habāb are the largest of all Tigrē-speaking tribes: they are nomads and Muhammedan. Being nomads, they have naturally a great many camels, scarcely any cattle, and no chickens at all. Now, it is a religious law with the Abyssinian Christians not to drink camel's milk, and this is one of the reasons why the people that are driven to lead a nomadic life, embrace the Muhammedan faith. However, even among the Habāb there are traces of former Christianity: a Muhammedan prayer consisting of the following lines was given to me.
samhān al-malik al-quddīs
s.inlizān al-malik al-maibiud
somhāan al-malik al-mauğiùd
quddìs quddīs quddīs
räbbi mal'ākyat warrī̄ll
Praise be to the Holy King
Praise be to the Worshipped King
Praise be to the Existing King
Holy Holy Holy
The Lord of the Angels and the Spirit. 
Two other customs practised alike by Christians and Muhammedans, which show that the latter at one time must have professed Christianity; are the following. At every meal the Trinity is invoked; small pieces of the food - usually a sort of polenta - are taken and thrown to the right, to the left and straight ahead, with the prayer sollāsé lahabakka walahabanna smay the Trinity give unto thee and unto us!«. Again, when the barkotta, or bread baked around a hot stone and in the ashes, the luubz almalla of the Arabs, is prepared at the halting place during a march, a small piece of bread is left aside and baked by itself; some one breaks it into as many pieces as there are people and deals it out among them, with the prayer

$$
\begin{aligned}
& \text { sollāsē sallīs } \\
& \text { 'ot 'ad hodng } \\
& \text { 'at gabai mallahai }
\end{aligned}
$$

Triune Trinity,

At home (left as) a protector, On the road a friend!

This custon is called sollāsé or $\bar{s}_{\bar{c}} \bar{k}{ }^{\prime} \bar{z} y \bar{o} b$.

The main divisions of the Habāb are the 'Ad Habtēs, 'Ad Taklēs and 'Ad Tə-Māryām, names that betray at once their Christian origin, viz. "Gift of Jesus", "Plant of Jesus" and "Gift of Mary". The 'Ad Taklēs and the 'Ad Tə-Māryām plough and sow to a certain extent. The third larger tribe are the Māryā, divided into the Red (Qayáh) and Black (Șallām) Māryā; they, too, are Mohammedans. Besides those there are a number of smaller tribes who use only Tigrē as their language, like the Mashālīt (in the Mänsa' territory), the Sâữā (with the 'Ad Tə-Māryām), the Aflenda (scattered over different tribes), the Bèt $\mathrm{Ma}^{c}$ alā and Bēt Ba'aššō in the North near Naqfā etc.; a complete list of them will be' given later. Bilingual are the 'Ad Hãsəri (in English territory), the Halanga, the Beni Amer (Min 'A $\bar{A}\left(2 r^{\prime}\right)$, who speak Həâārab and Tigrē; the Bogos, who speak Bilēn and Tigrē (one of their sub-tribes, however, the Bēt Dyūk, speak nothing but Tigrẽ); finally the Bãryā 
and Kunama, who have their own native African tongue, and the Arabic Rašaida are beginning to use Tigrë also.

The name Tigre for the common language of all these tribes is an artificial one used mainly by the Europeans, to distinguish it from the Tigrina. Formerly the natives themselves used to call it by different names according to the region or tribe, viz. higa $\bar{a} \bar{a} s \hat{y}^{c} \bar{a} i$ "language of Massaua", or hig $\bar{a} h a b \bar{a} b \bar{a} i{ }_{n}$ "language of the Habāb", but they have now begun to use the term togrie. On the other hand the settled, Tigriña-speaking people of Hamāsēn have a name for this language, zäräva $b \ddot{a} d a w i z$ i. e. Bedawin speech, but it is easily understood that those whom it concerned did not accept this somewhat derogatory term.

For the study of this language I have at present the following material.

I. An outline of a grammar, made at Gäläb, the materials for which were collected in oral conversations.

II. Texts.

I. Prose.

a) Translated: the Gospel of St. Mark, which I wrote down in transliteration after the dictation of a native.

b) Original Prose.

Fables and Tales.

dogan kal'ot sab 'a adu $g$ (the tale of the two donkeyowners, see below).

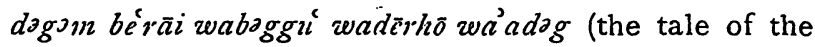
bull, the sheep, the chicken and the donkey).

dogan harāunya wahašil wa'onās (the tale of the boar, the fox and the man).

dogam' 'nās wa'arwē zuaruad hašil (the tale of the man, the serpent and the fox). mice).

dagam gōmāt 'anașịit (the tale of the council of the 
dogom luarāunya zuaharamms (the tale of the boar and the elephants).

dogam 'āu zuarvānin kulliu (the tale of all the domestic and wild animals).

dogom zua aga zuahabai zualuayat (the tale of the little monkey, i. e. cercopithecus, the monkey and the lion).

d’gan luayat wakarain wawad liasisll (the tale of the lion, the hyena and the fox).

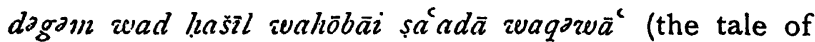
the fox, the stork and the raven).

d’gam wad luasil llarmāa kam tāla (the tale of the fox, how he followed the elephant).

dogam 'a $u$ (the tale of the domestic animals).

dogan dabtcir $\bar{a}$ avarvalag $\bar{a}$ (the tale of the scribe and the little monkey).

dagam bijlio (the tale of the jackal).

dəgam 'ossīt zuaba'asā 'ab zaban 'oșō 'agal 'agzuārōm latrqālatawōm (the tale of the woman and her husband who cheated their neighbours at the time of famine).

dagom dèrho (the tale of the hen).

dagam bāril wașalam (the tale of the honest man and the rascal).

dagan habai wašokan (the tale of the monkey and the gazelle).

dogan karāi wa'onās talājo (the tale of the hyena and his herdsman).

dogam harmāz wahamam wawaldī (the tale of the elephant and the leopard and his son).

dagan hamam wawad hasit (the tale of the leopard and the fox).

\section{Legends and Traditions.}

dagom hagara nāgrām (the tale of Hagara Nâgrām). dagan gondar (the tale of Gondar).

dagam salas la-mā̄ryāmāt, māryām çäwä́n wamāryām 
borìnt wantäryaim dabrä-sînä (the tale of the three Maries, Mary of Sion, Mary of the Solitude and Mary of Däbra$\operatorname{Sin} \bar{a})$.

dagain näbi miisã zuanäbi maluammed (the tale of Moses the Prophet and Mohammed the Prophet).

dogam kawàkìb (the tale of the stars).

This includes twelve different parts, first the names of the stars, then a number of myths concerning the Pleiads, the Polar Star, the Galaxy, the Twins etc., furthermore the various ways of determining constellations, beliefs about fallen stars (i. e. meteors), about the death of the moon (i. e. eclipse), the rise of the moon, and the omens connected with the stars.

dogom 'ad taklès (the story of the 'Ad Taklēs).

gadabo balqat (the battle of Balqat).

gadabō sangēer $\bar{a}$ (the battle of Sangērā).

degam dāh (the tale of the [bird called] Dāh, [who used to own camels and lost them because man took them from him]).

dogan lomam kam gandaba (the tale of the leopard in his old age).

dogam 'akarrìt (various legends concerning the hyenas and their tribes, religion etc.).

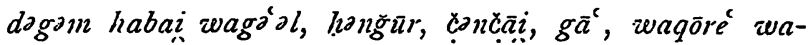
șāyat kullōm 'add̄am 'ot's 'ontōm 'alau (the tale of the monkey, the scarab, the wasp(?), the fly, the lizard, the frog and the worm(?), who all were men).

Two songs dealing with this tradition tinged with totemism, by Haməd Lūl and by Kəfāl.

dogam 'ob sábbat rabbi walaqōm 'addần (the tale concerning God and the uprising of man).

dogan 'arzeanm rarâyim (the tale of the Rōm giants). dagan qōm rōm ka'afó kam fana (the tale of the uprising of the Rōm, how it ended). 
Preliminary Report of the Princeton University Expedition to Abyssinia. I6 I

dagam kantēbấi șallīm wáalì wad máo (the tale of Kantebāi Șallīm and 'Alī, son of $\mathrm{Ma}^{\text {'ōo). }}$

\section{Customs and Beliefs.}

madər Mänsa' (the country of the Mänsa').

sor'at'anəs kam wáldayà (rites concerning women after childbirth).

sor at košbat (rites concerning circumcision).

sarat tomqat (rites concerning baptism).

sorat 'aqīb ba'alāt (rites concerning the keeping of festivals).

şrat sadaqat (rites concerning sacrifices).

sorat hașe (rites concerning betrothals).

sor at hodāi (rites concerning marriage).

sorat $m \bar{o} t m \bar{a}$ qabrat (rites concerning death and funerals).

'ob sab taluat laluassībo liāsāb (beliefs which they have about the people of below, i. e. the dead in the nether world). soul).

dogam gann (the tale of the owl, i. e. the bird of the

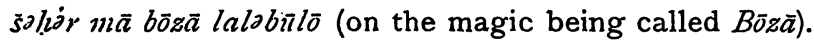
rvaddoganni lalabülō (on the so-called Waddogannì, i. e. the Abyssinian Lilith).

liāsāb 'ab yogar (beliefs about the hair).

' $\partial b$ 'asfār lalothassab (what is believed about nails).

'ab 'anğāb lahassizbō (what they believe about teeth).

'ob garōb 'addām lalotbahal (what is said about man's body).

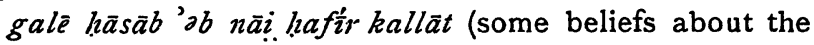
digging of clay).

'om 'arāwîttō latotbahal ka'junā wàdduúa (thus they represent the [animal] called chamaeleon).

dabbz (i. e. the tale of a small daemoniac animal which drives away all other animals).

Zeitschr. f. Assyriologie, XX. 
tokln ([beliefs about] the wolf).

dogan gararit (the tale of the lizards).

dogam qarogar wawaldä laamad (the tale of the beeeater and its son Haməd).

dogom llagal zuakaräkore (the tale of the guinea-hen and the quail).

man jans 'arāwî́t howāi lalabîló (on the serpent called lazwāi

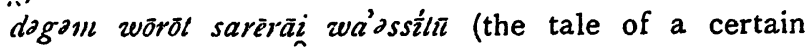
bird and his wife).

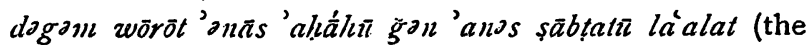
tale of a man whose cows were possessed by the women's demon).

fàlăt (omens, taken from the flight of birds, the braying of the ass etc.).

margam 'ačai (on the curse [resting upon] trees).

2. Poetry.

a) Various folk-songs, collected by $R$. SunDströM, numbering 549, some of which consist of as many as roo lines. The tribes speaking Tigrē are represented as follows: Mänsa' Bēt Abrəhē 229; Mänsa' Bēt Šăhaqán 3 I ; Bēt Dyūk (of Bogos origin) 17; the two Māryā tribes 62; 'Ad Tə-Māryām 70; 'Ad Habtēs 48; 'Ad Taklēs 54; Bēt Ma'alā and Bèt $B a^{c}$ aššo 8 ; from different smaller tribes (hailat habar man banābìn' 'addōtāt) 30.

b) Dirges, sung by women, in the majority from the Mänsa' Bēt Abrəhē: 40. These dirges are mostly composed in the Qinā metre.

Finally I also made a study of the names used in Tigrē, names of persons and of animals; and I collected a considerable number of photographs illustrating the life and the country of the Mänsa' and the physiognomy of the people, few of which, however, are distinct enough to give good reproductions.

Every member of the Mänsa' tribe has two names: 
I. the real name (som), used by the men; 2 . the surname (saqrāt), used by the women. A married person receives 3: a surname after the name of the first child, be it a boy

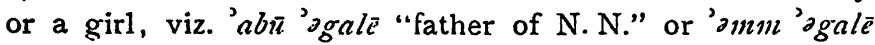
"mother of N. N." Everybody knows the names of his ancestors, generally up to five generations, sometimes seven and even ten. Boys learn the names of the ancestors of their friends. There are even certain men, like Yibbatit (who died recently; he was the author of Dr. Contr Rossini's Tradizione storiche dei Mensa), who know the ancestors of everybody in the tribe. There are a number of superstitions connected with the names; these will be described in detail in the Publications of this Expedition. It may suffice-here to say that a married woman must never pronounce neither sam nor saqrät $\mathrm{I}$. of her husband; 2. of her father-in-law; 3 . of her mother-in-law; 4. of the ancestor of her husband. She may, however, use the soqrāt of her mother-in-law, when the latter is not present. If a man comes to another tribe and has the same name as the husband or father-in-law or ancestor of his hostess, she cannot address him by his name, but must say moksa,

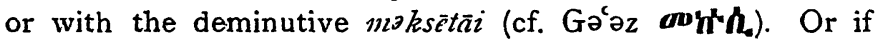
somebody wishes to know the name of a woman's husband, he asks her: "Whose name does your husband's name resemble?" She answers for instance: "The name of Abū Gamyā". The man asks again: "Is it "ətmān?" She says: "Yes". - The wild animals and dreaded diseases even have their "saqrätät", which are used in preference to the ordinary names, in order to avert the evil. The lion is called goliul, the hyaena zealat miisa or läbbät, the snake llabal madar (rope of the ground), the leopard avad 'abon (son of rocks); the smallpox ( $g a d r \bar{z}$ ) is called halíbät (milk), the malaria mașsat (disease), leprosy hałmàm 'ábi (great disease) etc.

I wrote down about 850 names of persons, male and female, som and saqrāt. 
Cattle play a very important role in the life of the Mänsa', and it is, therefore, very natural that cows claim the special attention of the people. Each cow is marked in four different ways:

1. According to the breed to which she belongs. Every breed has a sign of its own expressed by cuts in the ear, and 'ozon "ear" has become synonymous with gabilat "tribe".

2. According to the tribe of her owner. A tribal mark (Lalagat or 'alāmat, in Arabic wasm), consisting of a line, cross, hook, half-circle or the like, is branded upon the belly or the haunch of the animal. Special names for these tribal marks do not exist: in this the African nomads differ from their Asiatic fellows.

3. According to her colour. A great many words denoting colours and shades of colours of cattle exist in Tigrë.

4. By a proper name. Every cow has a name of her own. A certain number of names of cows and cattlebreeds and of words denoting colours were written down for me by NAFFA. It may be noted here that bullocks and heifers are called differently according to their age every year up to their sixth year.

To illustrate the character of some of the above mentioned tales, I give here a translation of a short but characteristic one, the tale of the two donkey-owners.

'Two men met each other; and each of them had a donkey. And the two men greeted each other; and also the two donkeys sniffed at each other putting their mouths together. And one of the two men asked the other saying: "We have greeted each other, but why do the donkeys put their mouths together?" The other man answered him: "Dost thou not know that? The donkeys have sent a strong donkey to the Lord to complain about them to the Lord that He might free them from under the [tyranny 
of] men. And the donkeys ask each other [now] whether he has returned or not."

It is said that the donkeys always ask each other about this matter when they put their mouths together. And from this parable we see that all creatures long for liberty:

\section{The Tigriña Language.}

The Tigriña Language is the daughter of literary Ethiopic, or Groz, and is spoken in the centre of the ancient Kingdom of Aksum, i. e. in the highlands of Northern Abyssinia, on both sides of the Māräb river, from about the Takkazē river in the south to a line drawn through Ad Tàklezan and Wārā in the North (see above p. 156). Beyond the Takkazē, Tigriña is spoken only in the province of Walqait. The main provinces where this language is used are, beginning from the North, Hamasenn, Dembelās, Saraiē, Okkulē Guzāi, Tigrai (Tigrē), Tambiēn. The largest of them is the province called by the inhabitants themselves Tigrai and in literature and by the Amharas Tigrē. From this the language received its name: with the termination of Amharic adjectives it is called $\operatorname{tagr} \tilde{\dot{n}} \dot{\tilde{n}} \bar{a}$, and this name, although coming from another language, is generally understood and used by the majority of those who wish to make a difference between the dialect of Tigrai and those of the other provinces. In the province of Tigrai the people speak generally of the Tigrai (tagrai $i$ ) language, and this name would be the most natural following the rules of the grammar of the language itself. Since, however, in scientific use it is preferable to have distinct terms for a group and for its constituents, and since $I$ have even heard people in Abyssinia speaking of togräi tograĩñā, meaning the Tigriña dialect of the province of Tigrai, I keep the term Tigriña including all the dialects of that language. Besides this the natives have other 
names which are in a way more significant and natural than the artificial distinction of Tigre and Tigriña, viz. zärävã hnvaša (in Tê. lighä kabasá) and zäräuã khostān (in Tê. luğa kos/ău). The name kabasā (havasā) (in the ancient inscriptions Habasat) practically includes those provinces which formed the center of the ancient Aksumitic Kingdom; the term "language of the Christians" has its origin in the fact that most - but not all - of those who speak Tigriña are Christians, and most of those who speak Tigrē are Muhammedans.

Material for the study of the Tigriña language was secured at Aksum during those days that were not taken up by the work of the Archaeological Expedition.

1. The Apologhi ed Aneddoti volte in lingua Tigriñina by Ghebre-Medhin Dighnei (Rome 1902), which were printed in Ethiopic characters, were transliterated after the dictation of my servant PaULUS MAN-Āmanō and translated after his interpretation.

2. The $47 \mathrm{I}$ proverbs published in Ethiopic characters in the Sillabario nella lingua Tigrinja, tradotto da $D^{\text {re }} C$. Winquist insieme con maestri indigeni (Asmara 1896) were transliterated and interpreted in the same way. A few proverbs were added to these.

3. In the same way were treated the 78 riddles published in Dr. Wingvist's Sillabario. A few riddles were taken down from the mouth of children at Abbā Pantaleon near Aksum.

4. A number of tales, legends and traditions, which I heard from different people at Aksum, were written down for me by PAulus and afterwards read and explained to me.

These are:-

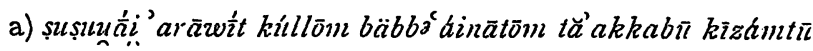
(the fable of all the various animals who united to make an excursion).

b) zantā 'abiuna gabra manfas qoddìs (the tale of our 
father Gabra Manfas Qəddūs, i. e. a famous Saint whose miraculous story is very popular and often told all over Abyssinia).

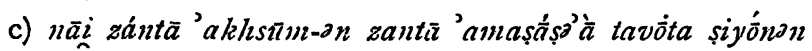
$n \bar{a} b^{\prime}$ ' $a k h s u m$ (about the story of Aksum and the story of the coming of the Ark of Șion to Aksum).

d) zantā hāṣdi Khấläb (the story of Emperor Kaleb).

e) A number of traditions about the ancient kings and the ruins of Aksum. It is interesting as an illustration 'of the manner in which genealogies are invented that, according to the belief of the present Aksumites, the following men are placed at the beginning of their history: Ham-Kush-'îtyōpiss-'Akhsūmāwĩ -'Akhsūm. The tomb of 'Ityōpis, the ancestor of all Ethiopians, is of course shown at A ksum, and the place is sacred, burning with fire every unholy or unclean thing that perchance may fall on it.

f) A ferv small texts in prose of different character.

The texts that are connected with the history of Aksum (c, d, e) will be edited and translated in the Publication of the German Expedition, whereas the others will be included among the Publications of this Expedition.

\section{Manuscripts.}

While in the Colonia Eritrea, I had occasion to visit only one Convent, viz. that of Däbra-Sinā, which is mentioned above on p. 156. I enquired at once about manuscripts and tried to secure some, but the monks said that those which they had were only a very few and necessary for their service. Most of their books had come from Däbra Bĩzän, the most important monastery of the present Colonia Eritrea. I made, however, a list of their manuscripts which I publish here in order to give an idea of a typical Abyssinian convent library. 
I. Biblical and Apocryphal Books.

IE RP. ( 12 copies of the Psalter, probably including the Biblical hymns).

Con2A (2 copies of the Gospels).

Z: $032 \Lambda: P \cdot d^{3}$ h (5 copies of the Gospel of St. John).

b h.h. A (Books of the New Testament exclusive of the Gospels).

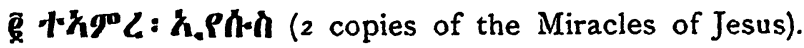

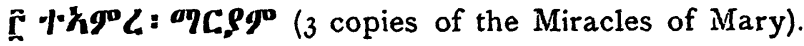

II. Books for the Service.

ê. (2 copies of the ritual of the mass).

IRQ (lectionary).

ong:h6.: hCintG (ritual of baptism).

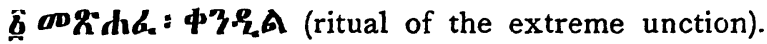

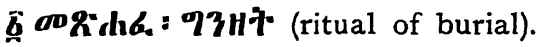

600\%h6.: \$SC (ritual of penitence for those who have had intercourse with infidel women).

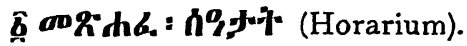

EhC794: $\boldsymbol{e}: 39 A$ (2 copies of the "Praises of the Virgin Mary").

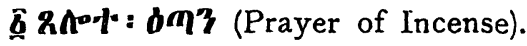

B.? (Book of Hymns).

600: $\mathbf{e} \cdot \mathbf{P}$ (Hymns used during Lent).

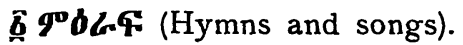

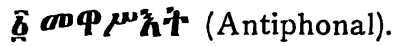

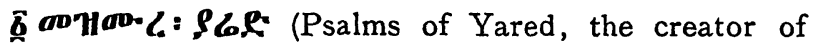
the Abyssinian chant).

III. Special Services and Homilies.

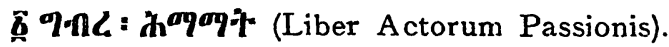

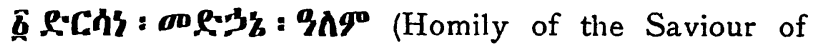
the World). 

chael).

E.PChy : aqhhA (2 copies of the Homily of St. Mi-

G. P.CAh : h.CakA (Homily of Uriel).

IV. Lives of Saints.

ểhhc: (2 Synaxaria).

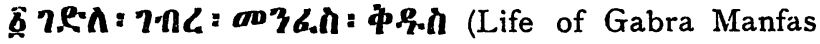
Qəddūs).

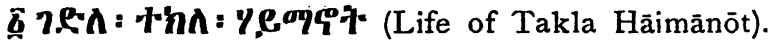

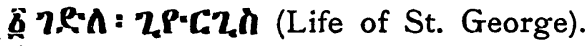

\section{Theology.}

e Yeaq41: hno. (2 copies of "the Faith of the Fathers").

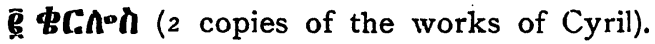

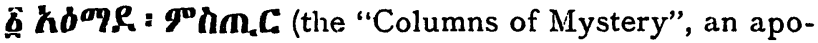
logetic work in Amharic).

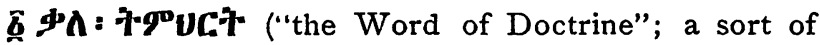
text-book for beginners in Abyssinian theology).

According to $A_{B \bar{U} N A}$ 'Āserēt, the prior of Däbra-Sinnā, the whole course of theology consists of the study of the

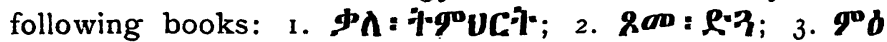

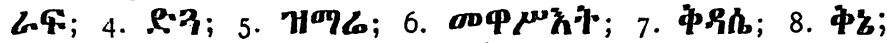

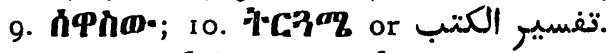

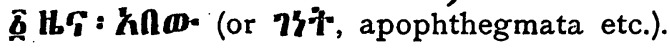

VI. Law and History.

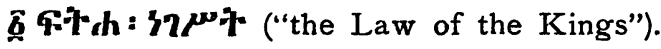

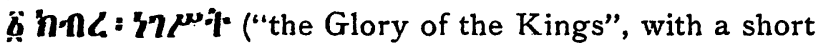
history of Muhammad Grāñ, Jhoh: $16 \log ^{3}$ ).

While at Aksum, I collected 149 manuscripts in Ethiopic and Amharic, and 167 magic scrolls. Of these, 48 manuscripts and 20 scrolls were embodied into the Collection of manuscripts of the Royal Library at Berlin: the rest will be described in detail in the Publications of this 
Expedition. There are no new or unique manuscripts among them, but several of them are old and rare. The collection of magic scrolls is especially rich and comprises all the different branches of Abyssinian magic literature. We are learning more and more how important it is for the study of more highly developed religions and of civilization in general to investigate magic in spite of all its abstruseness.

\section{Archaeological Work.}

A. The Greek inscription of Däqqī Maharī, discovered by $R$. Sundström.

After my departure from Abyssinia, while on my way back to Europe, I received a letter from Herr Sundström with the following P. S.:

'On my journey to Asmara I found, in the village of Däqqi Mahari, a stone with the following inscription:

\section{BACINEYCEKBACI \\ $\Lambda E W N A \equiv W M E I$ \\ TWNMETAC \\ CEBPOYOHC

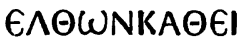 \\ $\triangle P Y C E \angle \bar{K} \Delta$

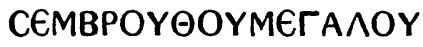 \\ BACI^EWC'.}

This is to be read and translated:

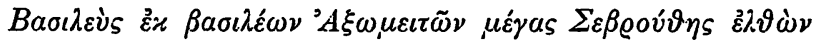

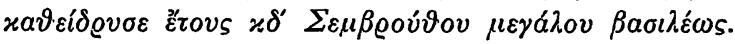

"The king of kings of Aksum, the great Se(m)bruthes came [to this place] and set up [this stone as a memory of his visit], in the year 24 of $\mathrm{Se}(\mathrm{m})$ bruthes, the great king."

The name of this king is not known to me from other sources, and it is therefore difficult to determine the date 
of his reign. All that can be said at present is that he must have been one of the pagan kings of Aksum. New inscriptions will probably throw more light on this interesting and thus far unique document. It is very important to know that the Kingdom of Aksum extended as far north as the place where this stone was found. Even farther north, at Aratu, in the region of the Bêt 'Auqē, Tenente Prva excavated last year the ruins of a very large structure, perhaps a temple. It is very likely that there was a sanctuary at Däqqī Maharī, and that the king, on his visit to the holy place, had his name carved on stone, like noble visitors of Egyptian temples, or like European potentates who climbed up to the dome of San Pietro in Vaticano.

Measurements and a detailed description of the monument were not given by Herr SunDsTRöM, but it is hoped that on another visit to the place, which is situated, as was said above on p. 153, on the direct road AsmaraGäläb, he will be able to furnish them.

\section{B. The ruins of Adulis and Gabaza.}

During my stay at Gäläb, Herr Sundströ̀r expressed the desire to visit and to study the ruins of ancient Adulis. Since I myself could not go there, but naturally considered such an investigation of the highest possible importance, I proposed to Mr. Garretr to make Herr SundSTRÖM's journey a part of the Princeton University Expedition. Mr. GARRETT agreed to this very willingly, and Herr Sundström went to Adulis with the permission of the Italian Government. Actual excavations, however, were prohibited by the Government, but the work done suffices to show that ancient Adulis, the sea-port of the Aksumitic Kingdom, still exists below the ground, and to make us hope that even the famous Adulitan inscription may be found some time when Italy will send out her own men to excavate there, or permit others to do so. From 
the following pages it will appear that R. Sundstroxs has been the real rediscoverer of ancient Adulis. I give here a literal English translation of his report which he sent me in Swedish.

\section{Report of an Expedition to Adulis. \\ By R. Sundstrom.}

Considering the fact that in the low-lands along the Red Sea the climate is exceedingly hot, I thought it wisest to visit the ruins of Adulis during the rainy season. I went down to the low-lands in January 1906 and continued to travel to the plain of Zula by permission of the Italian Government, and with a recommendation from ADEM Bey of Arkiko to the chief of Afta, a small village about twenty minutes north of the ruins of ancient Adulis.

A day's journey south of Arkiko or Dokono the large plain of Zula stretches between Mount Gadem to the north, Ra'ayo to the west, Fatar to the south and the Red Sea to the east. The name "Zula" means "the plain" in the language of the natives who are of the Assaorta (Saho) tribe, and according to them this is the plain of plains. Here lies, near the sea, the village of Zula, a village of considerable size, and half an hour to the north of it are the ruins of Adulis: their location is $15^{\circ} 17^{\prime} \mathrm{N}$. Lat. and $39^{\circ} 40^{\prime}$ E. Long. (Greenw.). A branch of the large Wa $\mathrm{Ca}^{\mathrm{c}}$ river passes near them.

Tuesday, January 16 , I went, accompanied by the chief of Afta, to the place of ancient Adulis in order to look over its ruins. I had imagined them to consist of huge walls, large hewn blocks and columns rising up to an imposing height or lying on the ground like fallen giants. But when I approached the place, I discovered nothing of all this: no massive walls, no high columns, no fallen pillars; not even a single really large stone did I find there. Eagerly I asked my companion several 


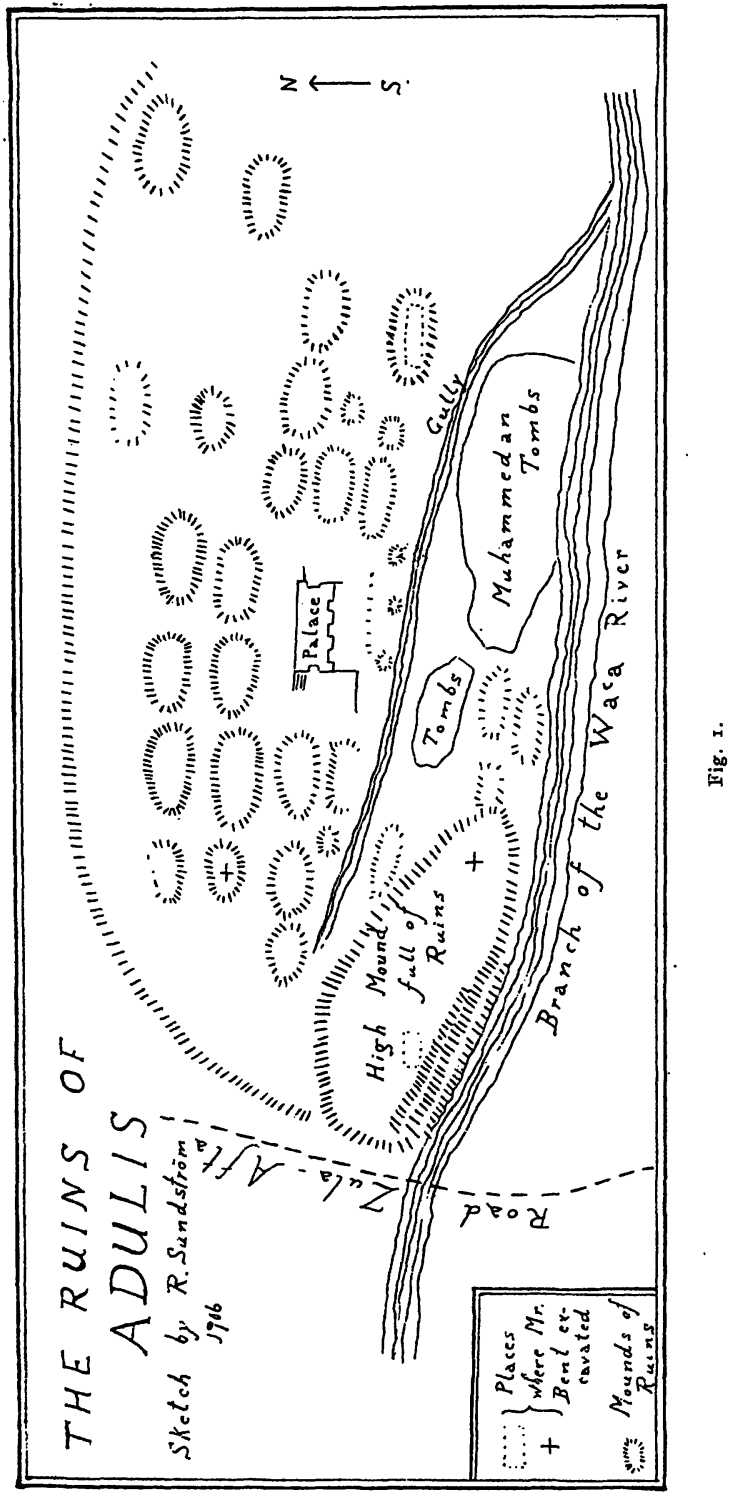


times where the ruins were, and pointing to a bot $11^{2}$ ) grove he said: "There they are." Finally we arrived at the spot. Where at one time the ancient center of commerce of the strong and mighty Kingdom of Aksum was situated, where life had been busy and strenuous, - there all was now quiet and dead. Həțūm bushes were thriving exuberantly, and the grass around and betwixt them was high and abundant.

But where were the ruins? I was very much astonished when my companion pointed at a few low piles of small black porous stones saying that those were the ruins. Wandering about I found in fact at several places parts of pillars which were said to have been excavated by an Englishman. ${ }^{2}$ ) In one of these places a large hole had been dug into the ground, and parts of beautiful columns and large slabs of stone had been unearthed. The natives have decorated the tombs of their ancestors with parts of pillars and with larger or smaller pieces of surprisingly beautiful and almost transparent plates of marble, which they have found on the hills. Upon careful examination lines of walls may be recognized here and there; whether they are walls of houses or courtyards remains to be determined. In a fer places the mounds are about two meters higher than the level of the surrounding plain. At various spots the ground is covered with sherds of different kinds of earthenware, snails, shells and corals. Furthermore there were a few beads, red, blue, green or white. Also some pieces of metal, viz. iron, copper and a brass-like alloy, were found. My attention was drawn especially to the fact that in certain places the small pieces of copper which I saw were melted and had the form of lead that had been melted and poured out and then had cooled off. It seems, therefore, that the ancient town was destroyed by a fire which melted the copper.

r) $h a t \bar{u} m=$ Suaeda monoeca Fk. (according to SchweinfuRTH).

2) Bent, The Sacred City of the Ethiopians, p. 230. 
As you go from south-west in the direction of north-east, the ruins take up a space about 800 meters long; but the width of this space is rather narrow. The above mentioned river branch seems to have changed its bed, in the course of time, further towards the north and to have undermined, disintegrated, and washed away the ruins on that side. This agrees with what the natives told me, viz., that after a heavy flood it happened that rusty swords and other iron objects were found. On account of their superstition, however, they had not dared to touch them, but had let the flood bury what it had thrown out on a former occasion.

The first glance at the ruins, therefore, did not promise much. But how long had this place been in such a state of desolation! When, for the last time, had here been heard the voice of the tradesman? When, for the last time, the clash of arms? When did the handmill grow for ever silent here? When was this town turned to ashes and gravel? That at some time a large and flourishing town with some magnificent houses did exist here, was proved by the excavated fragments of well hewn pillars and by the pieces of highly finished plates of marble.

I had come to this place in order to study the ruins, but I found little or nothing. I wished to see a little more, for above ground I had seen all. Therefore I resolved to undertake some small excavations. Of course, they could not ammount to very much, since I had neither means nor time for excavating on a larger scale. - But where should I put the first spade in the ground? Comparing all the pillar fragments in the different places, I found that everywhere those pieces were cut square with pointed corners and smooth sides (fig. 2), except in one place.

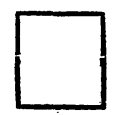

Fig. 2.

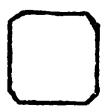

Fig. 3.

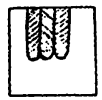

Fig. 4. 
Here the pillars were of larger dimensions, the corners were cut off, or the sides were grooved (figs. 3 and 4 ). Now I concluded that this mound, although not quite so high as the others near by, ought to contain a structure of unusual importance, and therefore, I chose it for my excavations. Soon after we had begun to dig, we met with a very well preserved wall ${ }^{2}$ ) of black porous stone, furthermore we found pieces of marble plates and of glass jars. We then excavated on the east side of the hill, a place which the natives had been using for burning tar. Here we began to dig a slanting trench into the hill, breaking away stone after stone with the hoe. The following day we found a wall here also. We continued to dig the trench deeper and longer, always keeping to the side of the same wall. We worked through the masses of stones to a depth of 4 meters, and there we found the foot of the wall. The form of this wall was unusual. It rises in steps, comparable to a staircase, each step being about half a meter high, and not quite a hand's breadth deep. ${ }^{2}$ ) The length of this wall seemed to be without end. Here on the west-side we unexpectedly came across a piece of a marble pillar hewn in screw form. ${ }^{3}$ ) This must have been of unusual beauty, when it was standing in its whole length. I was now once more confirmed in my opinion that we were here on the place of a large and important house or a palace.

I shall now give the results of my excavations without describing the progress of the work in detail. A sketch of "the Palace of Adulis" may serve as an illustration (fig. 5).

In this sketch the slanting lines indicate excavated portions, the dotted lines presumable course of the walls.

[I) This proved to be the south wall of the buildings.

2) This "graduated masonry" is characteristic of Abyssinian architecture; cf. the above mentioned Vorbericht d. D. Aksum-Expedition, p. 25.

3) I. e. probably a twisted column.] 


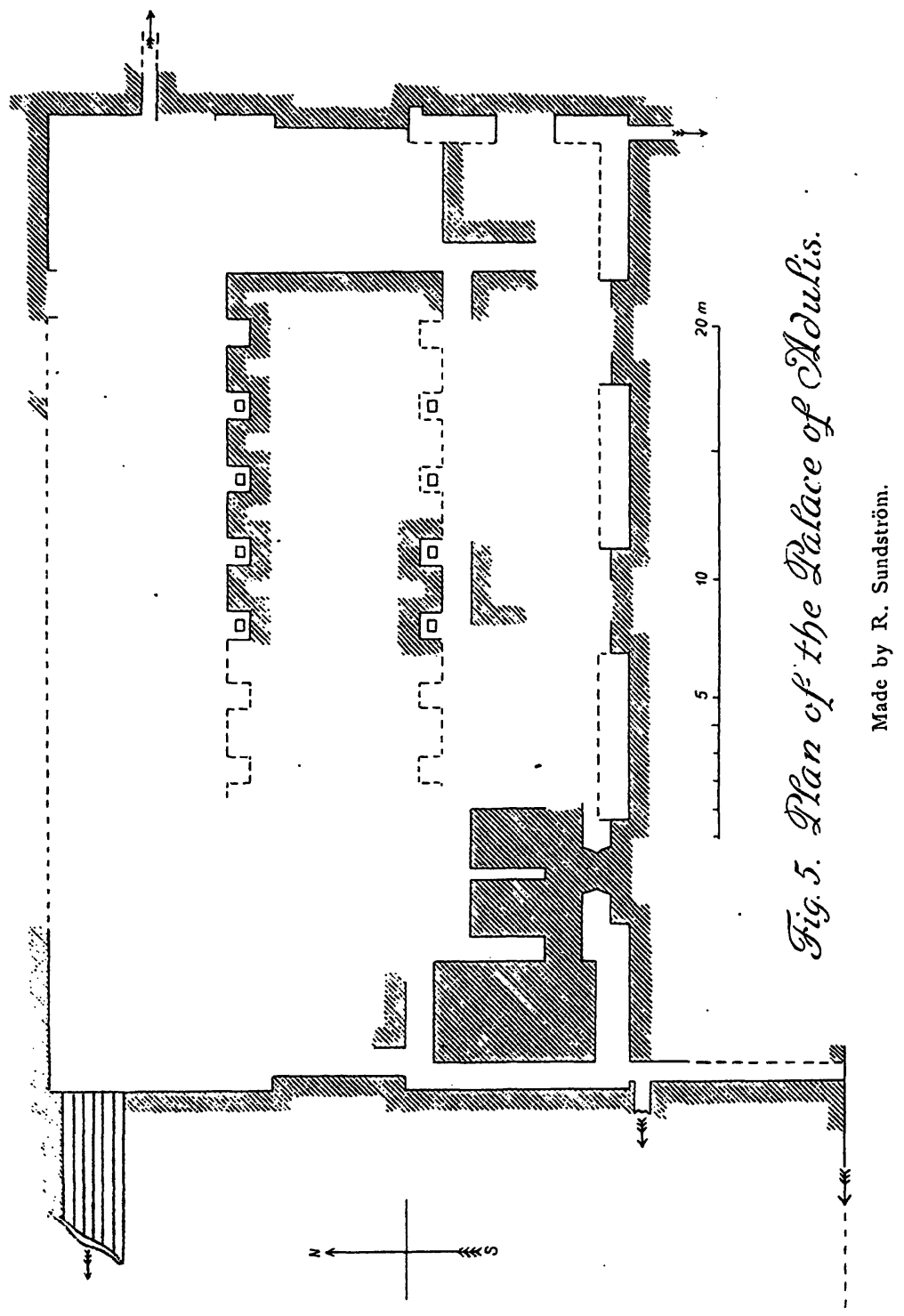

Zeitscbr. t. Asspriologio, $\mathrm{XX}$. 
The house in its present state represents only the lower story: the upper story has probably been destroyed, and its stones and mortar lie round about in heaps of débris. The walls are built in the above named "graduated style", except in the recesses for the doors in the south-wall, where the walls are straight: they consist on the outside of large ashlar blocks, some of which measure up to $2 \%$ meters in lenght, on the inside of smaller blocks. The whole length of the house measures in the groundfloor from $E$. to W. $38 \mathrm{~m}$; the width from N. to S. $22,50 \mathrm{~m}$. The southside is doubtless the front, and it seems to have had an enclosure in front of it, as is indicated by the adjoining walls in the east and the west corners. It is divided into four parts by the recesses made for the doors: in every one of these parts, which are each $6,50 \mathrm{~m}$ long, two openings are found of the following form, $\mathbf{T}$; these windows are $1,05 \mathrm{~m}$ high (perpendicularly) and wide (vertically), the opening itself having a width of $0,35 \mathrm{~m}$. On this side even the stucco is very well preserved. About the form of the northside I cannot make any definite statement, since I had no opportunity of excavating there, except near the corners. It seems to me, however, that the north-wall was somewhat different from the south-wall.

On the other hand, the east and the west sides are of the same style, i. e. in the center they both have a recess $5,10 \mathrm{~m}$ long, dividing either wall into two sections each $8,70 \mathrm{~m}$ long. But there is a conspicuous difference with regard to doors: the east side has two portals, the west side none. Moreover, there is a splendid flight of stairs on the west side. We could not excavate more than 7 very well preserved steps, and even these only for a space $6 \mathrm{~m}$ long. But these steps are certainly longer and more numerous. Did they lead up to the second story?

After we had, in this way, gone around the edifice in order to determine the outlines, as far as possible under the circumstances, we went back to the south side and 
set in at the first recess from the west. This one, as well as the other two, is $4 \mathrm{~m}$ wide. During our excavations in these recesses we found among the débris of the destroyed upper story a large amount of ashes and charcoal and half burnt trunks of cypress-trees. In the door-opening, which measures $\mathrm{I}, 60 \mathrm{~m}$, we discovered even the charred door-posts, undoubtedly also of cypress wood. It looks as if at the time when the town was looted and destroyed, all the combustible material at hand had been piled up in front of the doors leading into the lower story.

We now enter the room which has been excavated first. The floor is here made of pounded clay. In the center of the room there is a foundation wall $0.40 \mathrm{~m}$ wide, dividing it into two parts, each of a width of $2,30 \mathrm{~m}$. This wall is quite well preserved except in its front part. At the right and the left, doors were found leading into the inner rooms. Curiously enough the opening at the left was walled up. In this first room we found pieces of glass and a gold coin on the floor among the ashes and the charcoal.

In order to enter the room to the left more easily I had the walled-up door opened. This room is quite large, measuring $4 \mathrm{~m} \times 6,15 \mathrm{~m}$; and it is $3.50 \mathrm{~m}$ high up to the groove in the wall where the ceiling (or roof) adjoined. The floor was covered with two layers of well preserved tiles: the lower layer consisted of square tiles measuring $0,26 \times 0,26 \mathrm{~m}$, the upper of rectangular ones measuring $0,26 \times 0,12 \mathrm{~m}$. The stucco of the walls has now entirely disappeared. Excavating on this spot, we found some silver coins, a few of which are well preserved, especially those which we found lying in a roll. Near this, we found piles of bones, the greater part of which were decayed. The form of one of them, a thighbone, indicated that it was part of a human skeleton; and the same is true of a heavy collar-bone which was also found there. What purpose may this room have served? Was it an or- 
dinary prison? Probably not; for how could silver coins be found there? Or had some unfortunate person been walled in here to starve to death? Perhaps. - Beside these things we found here only a few pieces of glass and of metal.

Only these two rooms were excavated, but I conclude that in the lower story there were 7 rooms, I each on the north and the south sides, I room each on the east and the west sides, and a pillar-hall in the center, i. e. 16 rooms in all not counting the center hall. The foundations of five pillars on the north side and of two on the south side were unearthed. On eight of these foundations I have placed pillar-bases and upon them pieces of pillars which were found (cf. the plan).

Inasmuch as the work done was only reconnoitring work - successful, it is true - and cannot be termed real excavation, great finds of antiquities cannot be expected from it. Besides the pieces mentioned above we found fragments of marble slabs with reliefs of vines and grapes, some other marble ornaments, parts of a thin copper chain, nails and spikes of copper and pieces of painted glass. But how much is still hidden in these ruins! Whoever will come to undertake extensive excavations will find much.

A few words may be said here about some of the coins. ${ }^{x}$ ) One of the gold coins has on the averse a portrait surrounded by two palm-branches and the legend $\Gamma €+P C+E M[$ i. e. $\Gamma \varepsilon \varrho \sigma \varepsilon \mu]$, on the reverse a crowned figure also surrounded by two palm-branches within a circle, and arround the whole the legend BACINIAZWMI + [i. e. $\left.B a \sigma \iota \lambda(\varepsilon \dot{v} \varsigma)^{\prime} A(\xi) \omega \mu \iota \tau \tilde{\omega} \nu\right]$. The other gold coin, a little rubbed off, has on the averse the portrait of a man surrounded by two palm-branches within a ring and the legend $\mathrm{A}+\mid \mathrm{A}+\boldsymbol{\Theta}+\mathbf{\Lambda}+\left[\mathrm{i}\right.$. e. perhaps $\left.I \alpha \vartheta \lambda_{\iota} \alpha\right]$, on the reverse the same as the preceding one.

[1) A more detailed account of them, with reproductions, will be published later.] 
The silver coins are of a similar form and shape. On the averse there is the crowned figure of the king: the crown and the mouth are gilded (his words are like gold), and the legend reads $37 w k h h m$ [i.e. 37-w: khh-90, "King of Aksum"]. On the reverse there is a gilded cross, surrounded by a horseshoe-like ring, and the legend HPOAP| onflyt, and under the whole some destroyed letters [the

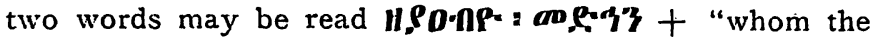
Saviour exalts", but for an accurate interpretation a careful study of the original is necessary]. The copper coins are not so well preserved; some of them are gilded around the portrait.

Finally I wish to add a short note about the port Gabaza, in Gə'əz $\mathbf{M} \mathbf{h}$. Heretofore it has been uncertain where this port was situated. According to Greek writers it lay twenty Olympic stadia or $3500 \mathrm{~m}$ from Adulis, but it is not said in which direction, north or east or southeast. At present the whole coast here is very shallow. Since there is no trace of such a place to the north of Adulis, we have to look for it in the other two directions. The natives themselves, especially the Danakil, carry on traffic along the sea-shore, and as a harbour or anchoring place they use Malcatto, situated due east of Adulis. Here the English had their harbour at the time of their Abyssinian war in 1868 , and from here they built their railroad to the Comaile valley, traces of which are still to be seen. One is led to believe, therefore, that this was possibly the place of the ancient harbour. There are, however, several reasons for assuming that ancient Gabaza was situated to the south-east of Adulis, and to the south of Malcatto.

Here, about tivelve minutes from the present seashore, there is a chain of small hills, the northernmost of which has a height of $61 \mathrm{~m}$ above the sea-level, while the rest slope down gradually until the last one rises very little above the ground. This chain is called by the natives

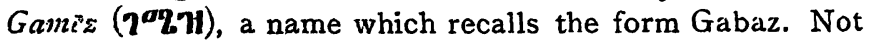


only does the similarity of the names advocate the identification of this place with the seaport of ancient Adulis, but several other circumstances make it almost certain. Between the northernmost hill and the others runs a gully of fresh water. When I visited the place, situated $1^{1} / 2$ hours from Adulis, I found near the water pits dug by the natives in order to water their cattle, large heaps of potsherds of different kinds like those found at Adulis, pieces of glass, broken tiles, beads, ashes and charcoal. The natives told me that they found such objects in the earth every year. This indicates that a town was situated here. On account of the name and of the fact that fresh water and ancient fragments are to be found here, I. presume that Gabaza, the harbour of Adulis, was situated on this spot. But it lies a short distance away from the shore. Was it then fit for a harbour? There is, of course, a considerable difference between the conditions of nowadays and those of 1500 to 2000 years ago, especially on a shore as low as this one consisting only of sand: furthermore, the rivers of the high-lands have carried with them, in the course of centuries, much sand and gravel, and thus they can and must have changed the whole shore a great deal. For this reason it is impossible to tell whether the former conformation of the shore made the place fit for a harbour or not.

Adulis as well as Gabaz await their excavator: after this discovery, he will not be long in coming. And when he comes, he will add greatly to our knowledge of history, especially of the history of the ancient Kingdom of Aksum. Let us hope that he may also find the famous Adulitan monument known to us through Kosmas Indikopleustes. 